\title{
Gastric Neuroendocrine Tumor Clinical Distant Metastasis TNM Finding v7
}

National Cancer Institute

\section{Source}

National Cancer Institute. Gastric Neuroendocrine Tumor Clinical Distant Metastasis

TNM Finding v7. NCI Thesaurus. Code $C 90118$.

A clinical finding about one or more characteristics of gastric neuroendocrine tumor, following the rules of the TNM AJCC v7 classification system as they pertain to distant metastases. 